\title{
Analisis Pengendalian Kualitas Super Absorbent Polymer Dengan Menggunakan Metode Six Sigma
}

\author{
Rosihin ${ }^{1}$, Laksamana Mujaddid Ulinnuha ${ }^{2}$, dan Dadi Cahyadi ${ }^{3}$ \\ Program Studi Teknik Industri, Fakultas Teknik, Universitas Serang Raya \\ kris.gusbiantoro@wilmar.co.id; I.mujaddid@gmail.com; dadicahyadi2012@gmail.com
}

\begin{abstract}
Abstrak -- Pengendalian kualitas merupakan suatu upaya untuk meningkatkan kepuasan pelanggan dan meminimalisir kerusakan. Super Absorbent Polymer merupakan bahan baku pembuatan popok bayillansia dan pembalut wanita. Pada Super Absorbent Polymer biasanya ditemukan kecacatan berupa kontaminasi warna yaitu terdapat warna gelap pada produk tersebut, salah cetak label kemasan dan rusaknya kemasan. Penelitian ini bertujuan untuk mengetahui nilai DPMO dan tingkat sigma, mengidentifikasi upaya yang dilakukan untuk mengurangi kecacatan, mengidentifikasi jenis kecacatan yang ada, dan mengetahui faktor utama penyebab kecacatan. Metode Six Sigma digunakan untuk menganalis data dengan tahapan define, measure, analyze, improve, dan control. Data yang digunakan adalah data kuantitatif yang didapat melalui observasi langsung mengenai kualitas. Dengan menggunakan metode six sigma dapat diketahui bahwa kualitas produk yang dihasilkan cukup baik yaitu 3,07 sigma dengan tingkat kerusakan 58.624 untuk sejuta produksi (DPMO). Tiga penyebab produk cacat tertinggi yaitu kontaminasi warna, sebanyak 93,34\%, Salah cetak sebanyak 3,55\%, dan rusaknya kemasan sebanyak 3,11\%. Faktor utama penyebab kecacatan adalah faktor mesin untuk jenis kecacatan kontaminasi warna. Jenis kecacatan salah cetak pada label kemasan dan rusaknya kemasan, faktor utamanya ialah faktor manusia.
\end{abstract}

Kata kunci: DPMO; Six Sigma; dan Super Absorbent Polymer

\begin{abstract}
Quality control is an effort to increase customer satisfaction and minimize damage. Super Absorbent Polymer which is a product as a raw material for making baby diapers / elderly and sanitary napkins. In Super Absorbent Polymer, defects usually found in the colour contamination that there is a dark colour on the product, print labels mistakes and packaging defects. This study aims to determine the value of DPMO and sigma level, identify the efforts which is taken to reduce disability, identify the types of disability, and find the main factors causing disability. Six Sigma method is used to analyze data with define, measure, analyze, improve and control. The quantitative data obtained by direct observation of quality problems. By using the method of six sigma can be seen that the quality of the resulting product is quite good that is 3.07 sigma with a damage rate of 58,624 for a million production (DPMO). The three highest defect product causes are color contamination of $93.34 \%$, misprint of $3.55 \%$, and packaging damage as much as $3.11 \%$. The main factor causing defects is the engine factor for the type of colour contamination defect,. The type of improper defects in the packaging labels and main factor for the packaging defects is the human factor.
\end{abstract}

Keywords: DPMO; Six Sigma; and Super Absorbent Polymer

\section{PENDAHULUAN}

Pengendalian kualitas sangat penting bagi perusahaan dan perlu untuk direalisasikan supaya perusahaan dapat mengetahui terjadinya penyimpangan dalam proses produksi sehingga perusahaan dapat meminimalisir atau mencegah terjadinya kerusakan sekecil mungkin. Akibat dari penyimpangan produksi akan menimbulkan kerugian besar bagi perusahaan baik dari segi kualitas maupun kuantitas.

Six sigma merupakan salah satu tool yang biasa digunakan untuk menjaga kualitas produk. Menurut Gaspersz (2005) six sigma merupakan suatu usaha peningkatan kualitas menuju target
3,4 kegagalan per satu juta kesempatan untuk setiap transaksi produk atau jasa. Six Sigma berusaha memperbaiki proses produksi dalam rangka mengurangi varian proses dan kepuasan pelanggan. Jadi six sigma merupakan suatu teknik pengendalian dan peningkatan kualitas yang merupakan terobosan baru dalam bidang manajemen kualitas.

Penerapan metode Six Sigma mampu mengurangi nilai DPMO. Sebelum penerapan nilai DPMO adalah 1733. Setelah penerapan mejadi 1122. Nilai sigma sebelum penerapan adalah 4,68 dan berubah menjadi 4,87 setelah penerapan. Selain itu penerapan metode Six 
Sigma mampu mengurangi biaya akibat kualitas rendah sebesar Rp. 16.650.000,00. (Khamaludin, 2017). Kaushik \& Kumar (2017) mendapatkan hasil bahwa penggunaan six sigma mampu meningkatkan nilai sigma dan menurunkan DPMO., Hasil penelitian ini sesuai dengan penelitian terdahulu yang telah dilakukan Gupta, et. al. (2016) dan Lei, et. al, (2013) mengenai aplikasi Six Sigma untuk mengurangi cacat (defect).

Super Absorbent Polymer merupakan produk yang digunakan sebagai bahan baku pembuatan popok bayi/lansia dan pembalut wanita. Kebutuhan dalam produk ini sangat tinggi setiap waktunya dan dilakukan penanganan yang harus benar-benar bersih dari kontaminasi metal. Hal ini dikarenakan produk langsung diaplikasikan pada kulit manusia.

Pada Super Absorbent Polymer (SAP) biasanya ditemukan kecacatan berupa kontaminasi warna yaitu terdapat warna gelap pada produk tersebut, dikarenakan produk SAP berwarna putih, maka sangat rentan sekali terhadap kontaminasi warna. Kecacatan berikutnya yaitu berupa salah cetak label pada kemasan, dan juga rusaknya kemasan yang berdampak pada penolakan produk oleh konsumen.

Penelitian ini bertujuan mengetahui nilai DPMO dan tingkat sigma pada Super Absorbent Polymer, mengetahui jenis cacat yang terjadi dan mengetahui faktor utama penyebab kecacatan Super Absorbent Polymer.

\section{METODOLOGI PENELITAN}

Metode yang digunakan mengacu pada prinsip-prinsip dalam metode Six Sigma. Metode ini digunakan untuk mengantisipasi terjadinya kesalahan atau defect dengan menggunakan langkah-langkah terukur dan terstruktur. Dengan data yang ada, maka Continuous improvement dapat dilakukan berdasar metodologi Six sigma yang meliputi DMAIC (Pande \& Holpp, 2002)

\section{Define}

Pada tahapan define ditentukan proporsi defect yang menjadi penyebab paling signifikan terhadap adanya kerusakan yang menjadi sumber kegagalan produksi. Langkah-langkah dalam define adalah mendefinisikan masalah standar kualitas produk yang telah ditentukan perusahaan, mendefinisikan rencana tindakan yang dilakukan berdasarkan hasil observasi, analisis penelitian, menetapkan sasaran dengan tujuan peningkatan kualitas Six sigma.

\section{Measure}

Pada tahapan measure dilakukan dengan
2 tahap berdasarkan pengambilan sampel pada perusahaan selama tahun 2015 :

\section{Analisis Peta Kendali ( P-Chart)}

Peta kendali $P$ mempunyai fungsi untuk mengetahui pengendalian kualitas sudah terkendali secara statistik atau belum. Peta kendali $\mathrm{P}$ digunakan pada perhitungan proporsi cacat dengan jumlah sample bervariasi. Peta kendali $P$ bermanfaat membantu mengendalikan kualitas produk dan memberikan informasi mengenai kapan dan di mana harus melakukan perbaikan produk (Khomah \& Rahayu, 2016). Kendali P sendiri berguna untuk menghitung perbandingan jumlah cacat terhadap sampel yang diamati.

Peta kendali $\mathrm{P}$ dipilih karena data yang digunakan adalah data atribut, sample yang digunakan memiliki varian jumlah. Peta Kendali $P$ dapat disusun dengan langkah sebagai berikut:

a) Pengambilan data penelitian

Data yang digunakan dalam analisis penelitian ini dihasilkan dalam kegiatan produksi Super Absorbent Polymer (SAP) pada tahun 2015.

b) Pemeriksaan karakteristik dengan menghitung nilai mean.

Perhitungan nilai mean untuk pemeriksaan karakteritik data dilakukan dengan menggunakan rumus di bawah ini:

$$
\begin{array}{cl}
C L=\bar{p}=\frac{\sum n p}{\sum n} \\
\mathrm{n} & : \text { jumlah sampel } \\
\mathrm{np} & : \text { jumlah kecacatan } \\
\mathrm{p} & \text { : rata-rata proporsi kecacatan }
\end{array}
$$

c) Menentukan batas kendali pengawasan yang dilakukan dengan UCL (Upper Control Limit / batas spesifikasi atas) dan LCL (Lower Control Limit / batas spesifikasi bawah).

UCL dan LCL dapat dilakukan dengan menggunakan rumus dibawah ini:

$$
\begin{aligned}
& U C L=\bar{p}+3 \sqrt{\frac{\bar{p}(1-\bar{p})}{n}} \\
& L C L=\bar{p}-3 \sqrt{\frac{\bar{p}(1-\bar{p})}{n}}
\end{aligned}
$$

$$
\begin{aligned}
& \text { UCL : Upper Control Limit } \\
& \text { LCL : Lower Control Limit } \\
& \text { P : rerata proporsi kecacatan n jumlah } \\
& \text { sampel }
\end{aligned}
$$


2. Menganalisis nilai sigma dan Defect For Milion Opportunitas perusahaan.

Tabel 1. Langkah menentukan DPMO

\begin{tabular}{|c|l|l|}
\hline Langkah & \multicolumn{1}{|c|}{ Tindakan } & Persamaan \\
\hline 1 & Proses apa yang ingin diketahui & - \\
\hline 2 & Berapa banyak unit diproduksi & - \\
\hline 3 & $\begin{array}{l}\text { Berapa banyak produk cacat } \\
\text { Hitung tingkat kecacatan berdasarkan } \\
\text { langkah 3 }\end{array}$ & - \\
\hline 4 & Tentukan CTQ penyebab produk cacat & Bangkah 3/ langkah 4 \\
\hline 5 & $\begin{array}{l}\text { Hitung Peluang tingkat cacat } \\
\text { karakterisitik CTQ }\end{array}$ & Langkah 4 / Langkah 5 \\
\hline 6 & Hitung kemungkinan cacat per DPMO & Langkah 6 x 1.000.000 \\
\hline 7 & Konversi DPMO kedalam nilai sigma & - \\
\hline 8
\end{tabular}

Sumber: (Muhaemin, 2012)

\section{Analyze}

Pada tahapan analyze melakukan identifikasi penyebab masalah dengan menggunakan diagram pareto dan diagram sebab akibat.

1. Diagram Pareto

Diagram Pareto merupakan diagram yang digunakan untuk mengidentifikasi dan mengurutkan penyebab cacat produk yang terjadi (Prabowo \& Subiyakto, 2017). Dengan diagram pareto diketahui jenis penyebab kecacatan yang paling dominan. Penyusunan diagram pareto dimulai dengan penyusunan tabel frekuensi kumulatif dari cacat produk.

2. Diagram sebab - akibat :

Diagram sebab akibat merupakan sebuah alat untuk membantu menggabungkan ide penyebab potensial dari suatu permasalahan. Masalah yang utama diposisikan sebagai kepala ikan. Sedangkan penyebab suatu masalah dilambangkan tulang ikan yang dihubungkan dengan kepala ikan. Tulang ikan yang paling kecil menggambarkan penyebab yang paling spesifik (Puspitasari, 2006). Diagram pareto dapat digunakan sebagai acuan pedoman teknis fungsi operasional proses produksi untuk memonitoring dan meningkatkan tingkat kualitas produk pada waktu bersamaan dengan meminimalkan potensi-potensi kegagagalan yang mungkin bisa terjadi.

\section{Improve}

Tahapan Improve adalah langkah keempat program Six Sigma. Dalam langkah improve dilakukan tahapan peningkatan kualitas Six Sigma melalui rekomendasi ulasan perbaikan, menganalisa lalu melakukan tindakan perbaikan yang sebaiknya dilakukan

\section{Control}

Control adalah tahapan meningkatkan kualitas dengan memastikan tingkat baru kinerja dalam kondisi sesuai dengan standar yang telah ditetapkan. Peningkatan nilai/level di dokumentasikan dan disebarkan sebagai langkah perbaikan untuk kinerja proses selanjutnya.

\section{PENGOLAHAN DATA DAN PEMBAHASAN}

Langkah-langkah pengolahan data:

\section{Define}

Mendefinisikan masalah yang terjadi atau menemukan penyebab defect paling potensial dalam menghasilkan produk Super Absorbent Polymer (SAP). Tiga penyebab paling potensial dalam menghasilkan produk akhir diidentifikasikan sebagai berikut:

i. Terdapat Black Partikel (Kontaminasi Warna) Produk Super Absorbent Polymer (SAP) yang berwarna putih sangat rentan sekali terhadap kontamiasi warna selain warna putih.

ii. Kesalahan Cetak Label pada Kemasan

Pada kemasan produk Super Absorbent Polymer (SAP) ada beberapa label yang tertera termasuk salah satunya tanggal produksi produk. Kesalahan kerap terjadi pada saat pencetakan pada kemasan produk yang mengakibatkan produk tersebut menjadi reject atau tidak layak diterima konsumen.

iii. Kerusakan pada Kemasan

Terdapat dua macam pengemasan pada produk Super Absorbent Polymer (SAP) yaitu kemasan Paper Bag dan Container Bag, 
dimana pada dua kemasan tersebut tidak luput dari kerusakan.

\section{Measure}

Dalam melakukan pengendalian kualitas secara statistik, langkah pertama yang akan dilakukan adalah membuat check sheet. Check sheet berguna untuk mempermudah proses pengumpulan data serta analisis. Selain itu pula berguna untuk mengetahui area permasalahan berdasarkan frekuensi dari jenis atau penyebab dan mengambil keputusan untuk melakukan perbaikan atau tidak. Uji kecukupan data tidak perlu dilakukan karena data yang ada bukan berupa sampel acak yang didapat dari observasi ataupun kuisioner melainkan data hasil analisa pada tahun 2015 yang sudah tersimpan di database perusahaan.

Tabel 2. Tabel Data Produksi dan Jumlah Cacat Tahun 2015

\begin{tabular}{|c|c|c|c|c|c|c|}
\hline \multirow[b]{2}{*}{ Bulan } & \multirow{2}{*}{$\begin{array}{l}\text { Jumlah } \\
\text { Produksi } \\
\text { (Ton) }\end{array}$} & \multicolumn{3}{|c|}{ Jenis Cacat (Ton) } & \multirow{2}{*}{$\begin{array}{c}\text { Jumlah } \\
\text { Produk } \\
\text { Cacat } \\
\text { (Ton) }\end{array}$} & \multirow{2}{*}{$\begin{array}{c}\text { Presentase } \\
\text { Produk } \\
\text { Cacat }(\%)\end{array}$} \\
\hline & & $\begin{array}{l}\text { Black } \\
\text { Partikel }\end{array}$ & $\begin{array}{l}\text { Salah } \\
\text { Cetak }\end{array}$ & $\begin{array}{c}\text { Cacat } \\
\text { Kemasan }\end{array}$ & & \\
\hline 1 & 15482 & 835 & 35 & 30 & 900 & $5,8 \%$ \\
\hline 2 & 13990 & 749 & 26 & 17 & 792 & $5,7 \%$ \\
\hline 3 & 15472 & 861 & 32 & 30 & 923 & $6,0 \%$ \\
\hline 4 & 15014 & 826 & 29 & 22 & 877 & $5,8 \%$ \\
\hline 5 & 15483 & 837 & 39 & 38 & 914 & $5,9 \%$ \\
\hline 6 & 8020 & 439 & 19 & 18 & 476 & $5,9 \%$ \\
\hline 7 & 15530 & 851 & 33 & 29 & 913 & $5,9 \%$ \\
\hline 8 & 15482 & 859 & 37 & 32 & 928 & $6,0 \%$ \\
\hline 9 & 15011 & 817 & 23 & 28 & 868 & $5,8 \%$ \\
\hline 10 & 15473 & 858 & 30 & 22 & 910 & $5,9 \%$ \\
\hline 11 & 4507 & 245 & 11 & 8 & 264 & $5,9 \%$ \\
\hline 12 & 15526 & 850 & 29 & 27 & 906 & $5,8 \%$ \\
\hline
\end{tabular}

Dari tabel 2. telah ditunjukkan, rata-rata cacat Super Absorbent Polymer (SAP) yang terjadi selama tahun 2015 sekitar $6 \%$. Hal ini mengindikasikan masih terjadi masalah dalam proses produksinya. Kemungkinan peningkatan kualitas masih bisa dilakukan untuk meminimalkan penyebab cacat yang terjadi dan melakukan perbaikan untuk meningkatkan kualitas produk yang dihasilkan. Dari varian cacat yang terjadi dapat dibagi menjadi tiga jenis cacat yaitu rusak karena kontaminasi warna ke dalam produk dengan jumlah cacat sebanyak 9027 Ton. Jumlah jenis cacat karena salah cetak pada kemasan sebanyak 343 Ton. Selanjutnya adalah jenis cacat berupa kerusakan pada kemasan sebanyak 301 Ton.

Berdasarkan gambar1. dapat dilihat bahwa data yang diperoleh seluruhnya berada dalam batas kendali yang telah ditetapkan. Hal ini menunjukkan pengendalian dari kerusakan yang stabil tetapi masih sangat tinggi yaitu sekitar $5.86 \%$. Ini juga menyatakan bahwa pengendalian kualitas Super Absorbent Polymer memerlukan adanya perbaikan untuk menurunkan tingkat kecacatan sehingga mencapai nilai maksimal sebasar $0 \%$.

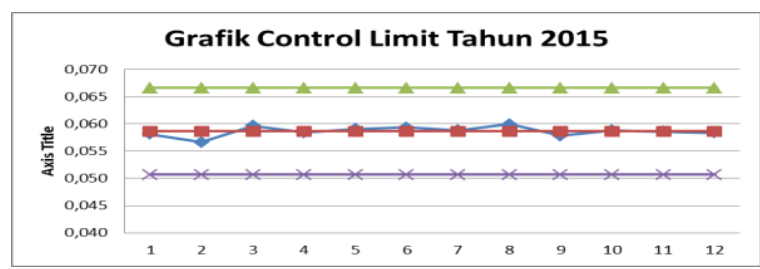

Gambar 1. Grafik Conrol Limit Tahun 2015

Hasil perhitungan pada tabel 3 , bagian produksi memiliki tingkat sigma 3.07 dengan kemungkinan kerusakan sebesar 58624 untuk sejuta produksi. Hal ini tentunya menjadi sebuah kerugian besar, apabila tidak ditangani tentunya mengakibatkan terjadinya pembengkakan biaya produksi. 
Tabel 3 Tabel Perhitungan DPU, DPMO dan Nilai Sigma

\begin{tabular}{|l|l|l|l|l|l|}
\hline Bulan & $\begin{array}{l}\text { Jumlah } \\
\text { Produksi } \\
\text { (Ton) }\end{array}$ & $\begin{array}{l}\text { Jumlah } \\
\text { Produk } \\
\text { Cacat (Ton) }\end{array}$ & DPU & DPMO & Nilai Sigma \\
\hline 1 & 15482 & 900 & 0,058 & 58132 & 3,08 \\
\hline 2 & 13990 & 792 & 0,057 & 56612 & 3,09 \\
\hline 3 & 15472 & 923 & 0,060 & 59656 & 3,06 \\
\hline 4 & 15014 & 877 & 0,058 & 58412 & 3,07 \\
\hline 5 & 15483 & 914 & 0,059 & 59032 & 3,06 \\
\hline 6 & 8020 & 476 & 0,059 & 59352 & 3,06 \\
\hline 7 & 15530 & 913 & 0,059 & 58789 & 3,07 \\
\hline 8 & 15482 & 928 & 0,060 & 59941 & 3,06 \\
\hline 9 & 15011 & 868 & 0,058 & 57824 & 3,08 \\
\hline 10 & 15473 & 910 & 0,059 & 58812 & 3,07 \\
\hline 11 & 4507 & 264 & 0,059 & 58576 & 3,07 \\
\hline 12 & 15526 & 906 & 0,058 & 58354 & 3,07 \\
\hline Rata-Rata & 13749,17 & 805,9167 & 0,06 & 58624 & 3,07 \\
\hline
\end{tabular}

\section{Analyze}

Penyebab kecatatan ada 3 yaitu kontaminasi warna, salah cetak label, dan rusaknya kemasan produk. Penyabab paling utama kecacatan yaitu kontaminasi warna dengan persentase dari total kecacatan adalah $93.34 \%$. Penyebab lainnya yaitu salah cetak label pada kemasan, dan rusaknya kemasan yaitu sebesar $3.55 \%$ dan $3.11 \%$.

Penelitian ini terfokus pada kontaminasi warna, salah cetak label pada kemasan, dan rusaknya kemasan. Karena hal ini merupakan kecacatan terbesar pada Super Absorbent Polymer pada tahun 2015.

Diagram sebab akibat memperlihatkan hubungan antara permasalahan yang dihadapi dengan kemungkinan penyebabnya serta faktor yang mempengaruhinya. Faktor yang mempengaruhi dan menjadi penyebab kerusakan produk secara umum dapat digolongkan sebagai berikut:

\section{a) Man (manusia)}

Para pekerja yang melakukan pekerjaan yang terlibat dalam proses produksi.

b) Material (bahan baku)

Segala sesuatu yang dipergunakan oleh perusahaan sebagai komponen produk yang akan diproduksi, terdiri dari bahan baku utama dan bahan baku pembantu.

\section{c) Machine (mesin)}

Mesin-mesin dan berbagai peralatan yang digunakan dalam proses produksi

d) Methode (metode)

Instruksi kerja atau perintah kerja yang harus diikuti dalam proses produksi.

e) Environment (lingkungan)

Keadaan sekitar perusahaan yang secara langsung atau tidak langsung mempengaruhi perusahaan secara umum dan mempengaruhi proses produksi secara khusus.

Setelah diketahui jenis kecacatan yang terjadi, maka langkah-langkah perbaikan untuk mencegah timbulnya kerusakan yang serupa bisa diambil. Hal penting yang harus dilakukan dan ditelusuri adalah mencari penyebab timbulnya kerusakan tersebut. Sebagai alat bantu untuk mencari penyebab terjadinya kecacatan tersebut, digunakan diagram sebab akibat atau yang disebut fishbone chart.

Kontaminasi warna selain warna putih merupakan masalah terbesar pada produk SAP. Hal ini disebabkan dari faktor-faktor sebagai berikut :

a) Faktor Mesin

Merupakan sebab utama yang mengakibatkan kerusakan jenis ini. Hal ini disebabkan oleh:

1. Mesin sudah tua sehingga sering terjadi pengikisan pada mesin yang 
mengakibatkan kontaminasi warna.

2. Kurangnya perawatan juga dapat mengakibatkan terjadinya pengikisan pada mesin..

b) Faktor Manusia

1. Kurang telitinya operator pada saat melakukan sampling dapat mengakibatkan benda asing masuk ke dalam proses dan dapat mengakibatkan kontaminasi warna.

2. Banyaknya operator baru yang bekerja pada plant Super Absorbent Polymer, dapat menyebabkan kontaminasi karena kurangnya pengalaman dari operator baru tersebut.

c) Faktor Material

Kualitas bahan baku yang kurang bagus yang digunakan pada proses dapat mengakibatkan perubahan warna yang terjadi pada produk tersebut.

d) Faktor Lingkungan

Kebersihan dari mesin dan sekitar mesin yang tidak dijaga dapat mengakibatkan kotoran atau benda asing yang berada di sekitar mesin dapat masuk dan terbawa masuk ke dalam proses yang dapat mengakibatkan kontaminasi warna.

Salah cetak label pada kemasan produk dapat mengakibatkan produk yang dikirim ke konsumen tidak sesuai standard karena informasi yang tertera pada label kemasan seperti tanggal, tipe produk, dan keterangan keterangan lainnya menjadi tidak jelas. Hal ini dapat disebabkan oleh:

a) Manusia

Merupakan sebab utama yang mengakibatkan kerusakan jenis ini. Hal ini disebabkan oleh:

1. Kurang telitinya operator dalam memasukkan data yang sesuai ke dalam komputer dapat mengekibatkan kesalahan pada sistem dalam membaca informasi dan mengakibatkan terjadinya kesalahan dalam pencetakan label.

2. Banyaknya operator baru yang bekerja pada plant Super Absorbent Polymer.

b) Faktor Metode

1. Bekerja dengan tidak sesuai SOP (Standar Operasional Prosedur) dapat mengakibatkan kesalahan pada saat memasukkan data.

2. Tidak adanya pengecekan ulang atau double check dapat mengakibatkan kekeliruan. c) Faktor Mesin

Kemungkinan terjadi error pada mesin pun tidak menutup kemungkinan merupakan penyebab utama kesalahan cetak pada label kemasan ini.

Rusaknya kemasan pada produk Super Absorbent Polymer sangat berakibat fatal karena dapat menyebabkan benda asing masuk ke dalam produk dan juga kadang mengakibatkan kebocoran produk sehingga produk tersebut tidak dapat diterima oleh konsumen.

a) Faktor Manusia

Merupakan sebab utama yang mengakibatkan kerusakan jenis ini. Hal ini disebabkan oleh:

1. Kurangnya kehati-hatian dalam pengemasan produk ke dalam kemasan dan juga pemindahan produk menggunakan forklift yang kurang hati-hati dapat mengakibatkan rusaknya kemasan.

2. Kurangnya pengalaman operator baru dalam penanganan produk di dalam kemasan dapat mengakibatkan rusaknya produk sebelum diantarkan ke konsumen.

b) Faktor Metode

1. Cara penyimpanan yang buruk pada gudang dan tidak sesuai pada tempatnya dapat mengakibatkan rusaknya kemasan sebelum digunakan.

2. Penanganan material pada saat datang dan keluar dari gudang yang tidak baik atau tidak sesuai juga dapat mengakibatkan rusaknya material sebelum digunakan.

c) Faktor Material

Kualitas bahan baku yang kurang bagus yang digunakan pada saat pengemasan dapat mengakibatkan rusaknya kemasan sebelum datang ke tangan konsumen.

d) Faktor Lingkungan

Kebersihan gudang yang tidak dijaga dapat mengundang serangga-serangga seperti rayap yang dapat merusak kemasan pada saat disimpan di gudang.

\section{Improve}

Merupakan rencana tindakan untuk melaksanakan peningkatan kualitas Six sigma. Setelah mengetahui penyebab kecacatan atas Super Absorbent Polymer, maka disusun suatu rekomendasi atau usulan tindakan perbaikan secara umum dalam upaya menekan tingkat kerusakan produk sebagai berikut: 
Tabel 4. Usulan Perbaikan untuk Cacat Kontaminasi Warna

\begin{tabular}{|c|c|c|c|c|}
\hline Unsur & Faktor Penyebab & Standar Normal & Usulan Tindakan Perbaikan & $\begin{array}{l}\text { Jangka } \\
\text { Waktu }\end{array}$ \\
\hline \multirow[t]{2}{*}{ Manusia } & $\begin{array}{l}\text { 1. Operator kurang teliti } \\
\text { dalam melakukan sampling }\end{array}$ & $\begin{array}{l}\text { Operator } \\
\text { langsung } \\
\text { melakukan } \\
\text { sampling ke } \\
\text { dalam proses } \\
\text { melalui samplin } \\
\text { point }\end{array}$ & $\begin{array}{l}\text { Lakukan pointing and calling } \\
\text { yaitu pengecekan yang lebih } \\
\text { dari satu kali sebelum } \\
\text { melakukan sampling }\end{array}$ & $\begin{array}{l}3-5 \text { menit } \\
\text { setiap } \\
\text { melakukan } \\
\text { pekerjaan }\end{array}$ \\
\hline & $\begin{array}{l}\text { 2. Operator baru yang } \\
\text { kurang berpengalaman }\end{array}$ & $\begin{array}{l}\text { Operator baru di } \\
\text { lakukan training } \\
\text { selama } 3 \text { bulan } \\
\text { lalu langsung } \\
\text { terjun ke } \\
\text { lapangan untuk } \\
\text { ikut bekerja }\end{array}$ & $\begin{array}{l}\text { Operator baru dilakukan } \\
\text { training selam } 3 \text { bulan namun } \\
\text { tidak langsung terjun ke } \\
\text { lapangan untuk bekerja } \\
\text { melainkan hanya membantu } \\
\text { operator senior dalam } \\
\text { bekerja minimal } 1 \text { tahun } \\
\text { sebelum bisa di lepas untuk } \\
\text { bekerja sendiri }\end{array}$ & $\begin{array}{l}1 \text { tahun } \\
\text { training } \\
\text { lapangan }\end{array}$ \\
\hline \multirow[t]{2}{*}{ Mesin } & $\begin{array}{l}\text { 1. Mesin sudah tua } \\
\text { sehingga sering terjadi } \\
\text { pengikisan pada mesin } \\
\text { yang mengakibatkan } \\
\text { kontaminasi warna pada } \\
\text { produk }\end{array}$ & $\begin{array}{l}\text { Pengecekan atau } \\
\text { patrol mesin } \\
\text { dilakukan setiap } \\
\text { satu bulan sekali }\end{array}$ & $\begin{array}{l}\text { Pengecekan atau patrol pada } \\
\text { mesin dilakukan setiap satu } \\
\text { minggu sekali dan jika } \\
\text { menemukan bagian mesin } \\
\text { yang sudah berkarat segera } \\
\text { dilakuka penggantian pada } \\
\text { part tersebut }\end{array}$ & $\begin{array}{l}2 \text { jam tiap } \\
\text { minggu }\end{array}$ \\
\hline & $\begin{array}{l}\text { 2. Kurangnya oerawatan } \\
\text { mesin dapat } \\
\text { mengakibatkan mesin } \\
\text { cepat terkikis dan } \\
\text { menyebabkan kontaminasi } \\
\text { warna }\end{array}$ & $\begin{array}{l}\text { Perawatan } \\
\text { dilakukan jika } \\
\text { adapart } \\
\text { mesinyang rusak } \\
\text { atau bermasalah }\end{array}$ & $\begin{array}{l}\text { Perawatan rutin dilakukan } \\
\text { satu bulan satu kali, dan } \\
\text { dibuatkan check list untuk } \\
\text { bagian apa saja yang sudah } \\
\text { dilakukan perawatan. }\end{array}$ & $\begin{array}{l}4 \text { jam tiap } \\
\text { bulan }\end{array}$ \\
\hline Material & $\begin{array}{l}\text { 1. Kualitas bahan baku } \\
\text { yang kurang bagus yang } \\
\text { digunakan di dalam proses } \\
\text { dapat mengakibatkan } \\
\text { kontaminasi warna }\end{array}$ & $\begin{array}{l}\text { Pengecekan } \\
\text { bahan baku yang } \\
\text { masuk hanya } \\
\text { berupa dokumen } \\
\text { saja }\end{array}$ & $\begin{array}{l}\text { Pengeceka bahan baku yang } \\
\text { masuk berupa dokumen cek } \\
\text { dan juga dilakukan sampling } \\
\text { pada bahan baku yang baru } \\
\text { masuk untuk memastikan } \\
\text { kualitas bahan baku tersebut. }\end{array}$ & $\begin{array}{l}30 \text { menit } \\
\text { pengecekan } \\
\text { tiap barang }\end{array}$ \\
\hline $\begin{array}{l}\text { Lingkun } \\
\text { gan }\end{array}$ & $\begin{array}{l}\text { 1. Kebersihan dari mesin } \\
\text { dan sekitar mesin yang } \\
\text { tidak dijaga dapat } \\
\text { mengakibatkan kotoran } \\
\text { atau benda asing yang } \\
\text { berada di sekitar mesin } \\
\text { dapat masuk dan terbawa } \\
\text { masuk ke dalam proses } \\
\text { yang dapat mengakibatkan } \\
\text { kontaminasi warna }\end{array}$ & $\begin{array}{l}\text { Tidak adanya } \\
\text { house keeping di } \\
\text { sekitar mesin } \\
\text { yang di pakai }\end{array}$ & $\begin{array}{l}\text { Dilakukan house keeping } \\
\text { satu minggu sekali di sekitar } \\
\text { mesin yang sedang di pakai, } \\
\text { dan membuat check list untuk } \\
\text { personil yang malakukan } \\
\text { kebersihan }\end{array}$ & $\begin{array}{l}2 \text { jam tiap } \\
\text { minggu }\end{array}$ \\
\hline
\end{tabular}


Tabel 5. Usulan Perbaikan untuk Cacat Salah Cetak

\begin{tabular}{|c|c|c|c|c|}
\hline Unsur & Faktor Penyebab & Standar Normal & Usulan Tindakan Perbaikan & $\begin{array}{l}\text { Jangka } \\
\text { Waktu }\end{array}$ \\
\hline \multirow[t]{2}{*}{ Manusia } & $\begin{array}{l}\text { 1.Kurang telitinya } \\
\text { operator dalam } \\
\text { memasukkan data } \\
\text { yang sesuia ke dalam } \\
\text { komputer dapat } \\
\text { mngekibatkan } \\
\text { kesalahan pada sistem } \\
\text { dalam membaca } \\
\text { informasi dan } \\
\text { mengakibatkan } \\
\text { terjadinya kesalahan } \\
\text { dalam pencetakan } \\
\text { label }\end{array}$ & $\begin{array}{l}\text { Operator langung } \\
\text { memasukkan data } \\
\text { ke komputer tanpa } \\
\text { melakukan } \\
\text { pengeceka terlebih } \\
\text { dahulu }\end{array}$ & $\begin{array}{l}\text { Sebelum operator melakukan } \\
\text { input data ke komputer maka } \\
\text { superior harus melakukan } \\
\text { pengecekan terhadap data } \\
\text { yang akan di masukkan } \\
\text { apakah sudah sesuai atau kah } \\
\text { belum }\end{array}$ & $\begin{array}{l}30 \text { menit } \\
\text { sekali } \\
\text { pengecekan }\end{array}$ \\
\hline & $\begin{array}{l}\text { 2. Banyaknya operator } \\
\text { baru yang bekerja } \\
\text { pada plant Super } \\
\text { Absorbent Polymer, } \\
\text { dapat menyebabkan } \\
\text { kontaminasi karena } \\
\text { kurangnya } \\
\text { pengalaman dari } \\
\text { operator baru tersebut. }\end{array}$ & $\begin{array}{l}\text { Operator baru di } \\
\text { lakukan training } \\
\text { selama } 3 \text { bulan lalu } \\
\text { langsung terjun ke } \\
\text { lapangan untuk ikut } \\
\text { bekerja }\end{array}$ & $\begin{array}{l}\text { Operator baru dilakukan } \\
\text { training selam } 3 \text { bulan namun } \\
\text { tidak langsung terjun ke } \\
\text { lapangan untuk bekerja } \\
\text { melainkan hanya membantu } \\
\text { operator senior dalam bekerja } \\
\text { minimal } 1 \text { tahun sebelum bisa } \\
\text { di lepas untuk bekerja sendiri }\end{array}$ & $\begin{array}{l}1 \text { tahun } \\
\text { training } \\
\text { lapangan }\end{array}$ \\
\hline \multirow[t]{2}{*}{ Metode } & $\begin{array}{l}\text { 1. Bekerja dengan } \\
\text { tidak sesuai SOP } \\
\text { (Standar Operasional } \\
\text { Prosedur) dapat } \\
\text { mengakibatkan } \\
\text { kesalahn kesalahan } \\
\text { yang seharusnya } \\
\text { dapat dihindari, } \\
\text { diantara lain } \\
\text { kesalahan pada saat } \\
\text { memasukkan data. }\end{array}$ & $\begin{array}{l}\text { Operator bekerja } \\
\text { hanya sesuai } \\
\text { instruksi oral atau } \\
\text { instruksi langsung } \\
\text { tanpa melakukan } \\
\text { pengecekan } \\
\text { terhadap SOP }\end{array}$ & $\begin{array}{l}\text { SOP di tempel di dekat area } \\
\text { kerja supaya operator yang } \\
\text { akan bekerja bisa ingat terus } \\
\text { dengan SOP nya }\end{array}$ & - \\
\hline & $\begin{array}{l}\text { 2. Tidak adanya } \\
\text { pengecekan ulang } \\
\text { atau double check } \\
\text { dapat mengakibatkan } \\
\text { kekeliruan yang } \\
\text { seharusnya dapat di } \\
\text { cegah jika melakukan } \\
\text { pengecekan ulang. }\end{array}$ & $\begin{array}{l}\text { Operator langsung } \\
\text { melakukan input } \\
\text { data ke komputer } \\
\text { tanpa adanya } \\
\text { pengecekan dua } \\
\text { kali terhadap data } \\
\text { yang akan di } \\
\text { masukkan } \\
\end{array}$ & $\begin{array}{l}\text { Operator melakukan } \\
\text { pengecekan sampai tiga kali } \\
\text { sebelum melakukan input data } \\
\text { ke komputer dan juga superior } \\
\text { harus memastikan apakah } \\
\text { data yang dimasukkan itu } \\
\text { benar atau tidak }\end{array}$ & $\begin{array}{l}10-15 \text { menit } \\
\text { setiap } \\
\text { memasukan } \\
\text { data }\end{array}$ \\
\hline Mesin & $\begin{array}{l}\text { 1. Kemungkinan terjadi } \\
\text { error pada mesin pun } \\
\text { tidak menutup } \\
\text { kemungkinan } \\
\text { merupakan penyebab } \\
\text { utama kesalahan } \\
\text { cetak pada label } \\
\text { kemasan ini. }\end{array}$ & $\begin{array}{l}\text { Pengecekan pada } \\
\text { mesin dilakukan } \\
\text { hanya ketika terjadi } \\
\text { abnormal atau } \\
\text { ketidak sesuaian }\end{array}$ & $\begin{array}{l}\text { Dilakukan pengecekan } \\
\text { minimal } 1 \text { bulan sekali dan } \\
\text { juga membuat check sheet } \\
\text { untuk item apa saja yang akan } \\
\text { di cek. }\end{array}$ & $\begin{array}{l}4 \text { jam tiap } \\
\text { bulan }\end{array}$ \\
\hline
\end{tabular}


Tabel 6. Usulan Perbaikan untuk Cacat Rusaknya Kemasan

\begin{tabular}{|c|c|c|c|c|}
\hline Unsur & Faktor Penyebab & Standar Normal & Usulan Tindakan Perbaikan & $\begin{array}{l}\text { Jangka } \\
\text { Waktu }\end{array}$ \\
\hline \multirow[t]{2}{*}{ Manusia } & $\begin{array}{l}\text { 1. Kurangnya kehati } \\
\text { hatian dalam } \\
\text { pengemasan produk } \\
\text { ke dalam kemasan dan } \\
\text { juga pemindahan } \\
\text { produk menggunakan } \\
\text { forklift yang kurang hati } \\
\text { hati } \\
\text { dapatmengakibatkan } \\
\text { rusaknya kemasan }\end{array}$ & $\begin{array}{l}\text { Pada saat operator } \\
\text { forklift akan } \\
\text { memindahkan } \\
\text { produk yang ada di } \\
\text { atas pallet } \\
\text { kemungkinan } \\
\text { produk tertusuk } \\
\text { forklift sangat tinggi } \\
\text { karena kurangnya } \\
\text { kehati hatian dari } \\
\text { operator }\end{array}$ & $\begin{array}{l}\text { Tingkatkan awarrness } \\
\text { operator dengan } \\
\text { mengadakan training, lalu } \\
\text { gunakan pelindung untuk } \\
\text { produk sehingga ketika } \\
\text { terjadi kesalahan yang } \\
\text { menyebabkan produk } \\
\text { tertusuk tidak langsung } \\
\text { robek karena ada pelindung } \\
\text { tersebut }\end{array}$ & - \\
\hline & $\begin{array}{l}\text { 2. Kurangnya } \\
\text { pengalaman operator } \\
\text { baru dalam } \\
\text { penanganan produk di } \\
\text { dalam kemasan dapat } \\
\text { mengakibatkan } \\
\text { rusaknya produk } \\
\text { sebelum di antarkan ke } \\
\text { konsumen }\end{array}$ & $\begin{array}{l}\text { Operator baru di } \\
\text { lakukan training } \\
\text { selama } 3 \text { bulan lalu } \\
\text { langsung terjun ke } \\
\text { lapangan untuk ikut } \\
\text { bekerja }\end{array}$ & $\begin{array}{l}\text { Operator baru dilakukan } \\
\text { training selam } 3 \text { bulan } \\
\text { namun tidak langsung } \\
\text { terjun ke lapangan untuk } \\
\text { bekerja melainkan hanya } \\
\text { membantu operator senior } \\
\text { dalam bekerja minimal } 1 \\
\text { tahun sebelum bisa di lepas } \\
\text { untuk bekerja sendiri }\end{array}$ & $\begin{array}{l}1 \text { tahun } \\
\text { training } \\
\text { lapangan }\end{array}$ \\
\hline \multirow[t]{2}{*}{ Metode } & $\begin{array}{l}\text { 1. Cara penyimpanan } \\
\text { yang buruk pada } \\
\text { gudangdan tidak } \\
\text { sesuai pada } \\
\text { tempatnya dapat } \\
\text { mengakibatkan } \\
\text { rusaknya kemasan } \\
\text { sebelum digunakan }\end{array}$ & $\begin{array}{l}\text { Kemasan yang } \\
\text { baru datang dari } \\
\text { supplier diletakkan } \\
\text { begitu saja tanpa } \\
\text { ada penutup } \\
\text { apapun }\end{array}$ & $\begin{array}{l}\text { Kemasan yang baru datang } \\
\text { dari supplier segera di } \\
\text { berkan penutup agar } \\
\text { terhindar dari debu dan juga } \\
\text { serangga, serta di lakukan } \\
\text { pengecekan rutin satu } \\
\text { bulan satu kali }\end{array}$ & $\begin{array}{l}30 \text { menit } \\
\text { setiap } \\
\text { barang }\end{array}$ \\
\hline & $\begin{array}{l}\text { 2. Penanganan } \\
\text { material pada saat } \\
\text { datang dan keluar dari } \\
\text { gudang yang tidak baik } \\
\text { atau tidak sesuai juga } \\
\text { dapat mengakibatkan } \\
\text { rusaknya material } \\
\text { sebelum di gunakan }\end{array}$ & $\begin{array}{l}\text { Bongkar muat di } \\
\text { lakukan oleh pihak } \\
\text { supplier sehingga } \\
\text { awareness atau } \\
\text { kepedulian } \\
\text { terhadap barang } \\
\text { kurang }\end{array}$ & $\begin{array}{l}\text { Bongkar muat di lakukan } \\
\text { oleh pihak PT. NSI } \\
\text { sehingga awareness } \\
\text { terhadap bahan baku bisa } \\
\text { lebih tinggi dan } \\
\text { memindahkannya lebih hati- } \\
\text { hati. }\end{array}$ & $\begin{array}{l}3 \text { jam } \\
\text { sekali } \\
\text { bongkar } \\
\text { muat }\end{array}$ \\
\hline Material & $\begin{array}{l}\text { 1. Kualitas bahan baku } \\
\text { yang kurang bagus } \\
\text { yang digunakan pada } \\
\text { saat pengemasan } \\
\text { dapat mengakibatkan } \\
\text { rusaknya kemasan } \\
\text { sebelum datang ke } \\
\text { tangan konsumen }\end{array}$ & $\begin{array}{l}\text { Pengecekan bahan } \\
\text { baku yang masuk } \\
\text { hanya berupa } \\
\text { dokumen saja }\end{array}$ & $\begin{array}{l}\text { Pengeceka bahan baku } \\
\text { yang masuk berupa } \\
\text { dokumen cek dan juga } \\
\text { dilakukan sampling pada } \\
\text { bahan baku yang baru } \\
\text { masuk untuk memastikan } \\
\text { kualitas bahan baku } \\
\text { tersebut. }\end{array}$ & $\begin{array}{l}30 \text { menit } \\
\text { setiap } \\
\text { barang }\end{array}$ \\
\hline Lingkungan & $\begin{array}{l}\text { 1. Kebersihan gudang } \\
\text { yang tidak dijaga dapat } \\
\text { mengundang serangga } \\
\text { serangga seperti rayap } \\
\text { yang dapat merusak } \\
\text { kemasan }\end{array}$ & $\begin{array}{l}\text { House Keeping } \\
\text { dilakukan satu } \\
\text { bulan sekali tapi } \\
\text { tidak pernah ada } \\
\text { penyemrotan untuk } \\
\text { hama seperti rayap } \\
\text { dsb }\end{array}$ & $\begin{array}{l}\text { House keeping dilakukan } \\
\text { dua minggu sekali dan juga } \\
\text { di lakukan penyemprotan } \\
\text { hama berupa pestisida } \\
\text { yang aman dan ramah } \\
\text { lingkungan }\end{array}$ & $\begin{array}{l}2 \text { jam } \\
\text { tiap } \\
\text { minggu }\end{array}$ \\
\hline
\end{tabular}




\section{Control}

Merupakan tahap analisis terakhir dari proyek six sigma yang menekankan pada pendokumentasian dan penyebarluasan dari tindakan yang telah dilakukan meliputi:

1. Melakukan perawatan dan perbaikan mesin secara berkala

2. Melakukan pengawasan terhadap bahan baku dan karyawan bagian produksi agar mutu barang yang dihasilkan lebih baik.

3. Melakukan pencatatan dan penimbangan seluruh produk cacat setiap hari dari masingmasing jenis dan mesin, yang dilakukan oleh karyawan dalam proses produksi.

4. Melaporkan hasil penimbangan produk cacat berdasarkan type produk cacat kepada supervisor.

5. Total produk cacat dalam periode satu bulan dicantumkan dalam monthly manager. Scorecard atas pertanggungjawaban manajer produksi untuk dilaporkan pada presiden direktur.

\section{KESIMPULAN}

Berdasarkan pengolahan data yang telah dilakukan didapatkan nilai sigma 3.07 dengan kemungkinan kerusakan sebesar 58624 untuk sejuta produksi (DPMO). Hal ini menjadi sebuah kerugian yang sangat besar apabila tidak ditangani tentunya mengakibatkan pembengkakan biaya produksi.

Jenis-jenis kerusakan atau reject yang sering terjadi pada Super Absorbent Polymer yaitu disebabkan karena kontaminasi warna sebanyak 9027 ton, salah cetak label sebanyak 343 ton, serta rusaknya kemasan produk sebanyak 301 ton. Berdasarkan diagram sebab akibat, faktor utama penyebab kecacatan pada produk Super Absorbent Polymer (SAP) adalah faktor mesin untuk jenis kecacatan kontaminasi warna, lalu untuk jenis kecacatan salah cetak pada label kemasan faktor utamanya yaitu faktor manusia,sementara untuk jenis kecacatan rusaknya kemasan faktor utamanya ialah faktor manusia.

\section{DAFTAR PUSTAKA}

Gaspersz, V. (2005). Sistem Manajemen Kinerja Terintegrasi Balanced Scorecard Dengan Six Sigma Untuk Organisasi Bisnis dan Pemerintah. Jakarta: Gramedia Pustaka Utama.

Gupta, A., Sharma, P., Malik, S. C., Agarwal, N., \& Jha, P. C. (2016). Productivity Improvement in the Chassis Preparation Stage of the Amplifier Production Process: A DMAIC Six Sigma Methodology.
International Journal of Reliability, Quality \& Safety Engineering, 23(6), 1-13.

Kaushik, P., \& Kumar, S. (2017). An application of six sigma for SMEs: A case study. Management Science Letters, 7(3), 145152.

Khamaludin. (2017). Implementasi Six Sigma Untuk Menurunkan Jumlah Cacat Pinhole pada Belt Drive Variable Speed. Jurnal Teknik Ibnu Sina, 2(1), 57-69.

Khomah, I., \& Rahayu, E. S. (2016). Aplikasi Peta Kendali $p$ sebagai Pengendalian Kualitas Karet di PTPN IX Batujamus/Kerjoarum. Journal of Agribusiness and Rural Development Research, 1(1), 12-24.

Lei, G., Zhu, J. G., Guo, Y., Xu, W., \& Shao, K. R. (2013). Robust Design Optimization of PM-SMC Motors for Six Sigma Quality Manufacturing. IEEE Transactions on Magnetics, 49(7), 3953-3956.

Muhaemin, A. (2012). Analisis Pengendalian Kualitas Produk dengan Metode SIX Sigma pada Harian Tribun Timur. Skripsi. Makasar: Fakultas Ekonomi dan Bisnis Universitas Hasanudin.

Pande, P., \& Holpp, L. (2002). What is six sigma? New York: McGraw- Hill.

Prabowo, R., \& Subiyakto, H. (2017). Analisis Peningkatan Kualitas Produk Precast Concrete Dengan Pendekatan Statistical Process Control dan Quality Function Deployment. In Seminar Nasional IENACO (pp. 499-506). Universitas Muhammadiyah Surakarta.

Puspitasari, E. (2006). Analisa Pengukuran Linier Sebagai Upaya Pengendalian Kualitas Produk Dengan Metode Control Chart. InfoTeknik, 6(1), 49-54. 